DOI: https://doi.org/10.36910/6775-2524-0560-2021-42-16

УДК 681.3.05

Чернишов Костянтин Андрійович, аспірант

http://orcid.org/0000-0002-8639-2732

Майданюк Володимир Павлович, к.т.н., доцент

Арсенюк Ігор Ростиславович, К. т. н, доцент

http://orcid.org/0000-0003-4045-6144

Малініч Ілля Павлович, асистент

http://orcid.org/0000-0002-5862-3732

Вінницький національний технічний університет

\title{
АНАЛІЗ ТА КЛАСИФІКАЦІЯ ВЕНДИНГОВИХ СИСТЕМ ТА ЇХ СТРУКТУРНИХ РЕАЛІЗАЦІЙ
}

Чернишов К., Майданюк В., Арсенюк I. Малініч І. Аналіз та класифікація вендингових систем та їх структурних реалізацій. У статті розглянуто вендингові системи та вендингові пристрої, їх складові та залежності між функціональним призначенням i апаратним забезпеченням. Наведено функціональні різновиди терміналів самообслуговування, виокремлено їх основні класифікативні відмінності. Проведено їх порівняльний аналіз, розглянута технічна сторона, принципи роботи та приведені приклади роботи розглянутих алгоритмів. Розглянуто основні аспекти функціонування вендингових систем як сукупність теорії автоматів і теорії масового обслуговування. Наведено список типових прикладних апаратно-програмних реалізацій вендингових технологій. Проведено аналіз ключових алгоритмів роботи терміналів і автоматів самообслуговування. Визначено провідні напрямки розвитку і сфери досліджень, направлених на вдосконалення сучасного стану вендингових систем.

Ключові слова: вендинг, самообслуговування, термінал, автомат.

Чернышов К.А., Майданюк В. П., Арсенюк И. Р., Малинич И. П. Анализ и классификация вендинговых систем и их структурных реализаций. В статье рассмотрены вендинговые системы и вендинговые устройства, их составляющие и зависимости между функцио-нальным назначением и аппаратным обеспечением. Приведены функциональные разновидности терминалов самообслуживания, выделены их основные класификативни различия. Проведен их сравнительный анализ, рассмотрена техническая сторона, прин-ципы работы и приведены примеры работы рассмотренных алгоритмов. Рассмотрены основные аспекты функционирования вендин-говых систем как совокупность теории автоматов и теории массового обслуживания. Приведен список типичных прикладных аппа-тно-программных реализаций вендинговых технологий. Проведен анализ ключевых алгоритмов работы терминалов и автоматов самообслуживания. Определены ведущие направления развития и сферы исследований, направленных на совершенствование современного состояния вендинговых систем.

Ключевые слова: вендинг, самообслуживания, терминал, автомат.

Chernyshov K. A., Maidaniuk Volodymyr Pavlovych, Arseniuk Ihor Rostyslavovych, Malinich I. Analysis and classification of ventenium systems and their structural implementation. The article deals with vending systems and vending devices, their components and dependencies between functional purpose and hardware. The functional variants of self-service terminals are presented, their main classification differences are distinguished. Their comparative analysis, the technical side, the principles of work and the examples of the work of the considered algorithms are considered. The basic aspects of the functioning of vendin-gov systems as a totality of the theory of automata and the theory of mass service are considered. The following is a list of typical application software applications for vending technology. The analysis of key algorithms of operation of terminals and selfservice machines is carried out. The main directions of development and areas of research aimed at improving the modern state of vending systems are determined.

Keywords: vending, self-service, terminal, automatic machine.

Вступ. 3 початку існування людства, людина прагнула змінити реальність свого існування: полегшити працю, покращити ефективність витрат часу і енергії. Звідси виникав окремий напрямок людської діяльності - створення засобів та інструментів праці, виробництва. Колесо, зброя, сільськогосподарське знаряддя, а згодом і цілі екосистеми життєзабезпечення невпинно втілювалися у життя людини, стаючи його невід'ємною частиною [1].

3 приходом епохи капіталізму, на допомогу виробництвам приходили механізми, а згодом - i напівавтоматичні системи. Ефективність виробництва зростала експоненціально. Під впливом значних досліджень у області математики, кібернетики, у напрямку теорії автоматів розвивається діяльність 3 побудови обчислювальних машин, а згодом їх варіації впроваджувалися і в промисловість. Автоматизація зайняла позиції провідного напряму розвитку всіх сфер людської діяльності. Від колеса до мікроконтролера. 
Актуальність. Як у світі взагалі, вендинг, як сучасний торговельний сервіс в Україні, зокрема, динамічно розвивається. Роздрібна торгівля, займаючи провідну галузь людського побуту, створює нові варіації розподілу робочих місць і загальноекономічних процесів.

Сучасний споживчий ринок $є$ відносно розвиненим: насичення товарами, що відповідають попиту населення, не оцінюється як вичерпне, але знаходиться на рівні достатнього. Динамічність обсягів і структура продажу товарів і послуг поступово набуває все більшої стійкості: змінюється співвідношення кількості продажів і кількості магазинів. Така тенденція одночасно пов'язана як 3 появою інтернет-магазинів (варіантів продажу без торговельних площ), так і зі скороченням числа самих магазинів на користь асортименту та, як наслідок, площі самих магазинів.

Таким чином, ключовим фактором, що стимулює прогрес, $є$ мінімізація витрат, що забезпечує процес доставки товарів покупцеві. В сучасних економічних умовах зростає важливість організації ефективного процесу розподілу в роздрібній торгівлі. Він $€$ одним 3 основних критеріїв для отримання комерційним підприємством прибутку і підтримання стабільності в умовах посилення конкуренції на ринку, серед комерційних підприємств та торгових марок, на одного споживача [2].

Мета. Метою роботи є аналіз сучасного стану застосування вендингових систем, варіації їх структурних реалізацій та визначення ролі вендингових пристроїв в сучасних інформаційних системах.

Задачі.

Класифікація вендингових систем.

1. Аналіз історичних передумов появи різноманіття вендингових систем та їх еволюції.

2. Аналіз структурних реалізацій сучасних вендингових пристроїв.

3. $\quad$ Аналіз типових алгоритмів роботи вендингових автоматів.

4. Методи розробки та побудови архітектури вендингових систем.

5. Визначення напрямків розвитку досліджень та розробки вендингових пристроїв.

Класифікація вендингових систем. Серед вендингових систем слід одразу виокремити два сімейства: автомати для надання послуг і автомати для продажу товарів (торгові автомати). Подальшу класифікація цих сімейств буде розглянуто з точки зору функціональних особливостей та особливостей у застосуванні. Почати доцільно з торгових автоматів [3].

По виду товару, що реалізується:

1. Торгові автомати для продажу продовольчої продукції.

Сюди віднесемо кавові автомати, автомати з продажу розливної газованої та питної (побутової) води, автомати з продажу свіжого соку, квасу, питної види. Більш рідкісні види апаратів: для продажу кисневих коктейлів, молочних коктейлів, чайні торговельні апарати та інші. Що стосується продовольства не радкої консистенції - це, в першу чергу, снекові автомати, а також автомати для продажу гарячої їжі, піци, попкорну, цукрової вати, цукерок, жуйки та інші вендингові машини, що пропонують покупцеві готові до вживання продукти харчування. Отже, класифікацію продовольчих вендингових систем ми можемо сформулювати наступним чином:

- За ступенем готовності продовольчої продукціі: ті, що готують продукт під час використання i ті, що продають вже готову продукцію;

- За консистенцією продовольчого товару: рідкі і паковані (не рідкі);

- За принципом видачі штучної продукції: барабанні, ліфтові, спіральні;

- За наявністю продукції, яка має короткий термін придатності.

2. Торгові автомати для продажу непродовольчих товарів.

Через торговельні автомати можна продавати все, що не заборонено законодавством, однак в нашій країні працює не надто велика кількість апаратів цього типу. Це лінзомати, автомати з продажу живих квітів і ще кілька видів (оатоматизовані газетні кіоски та кіоски 3 продажу відео-дисків). У світовій практиці вендинга цей список, звичайно, значно ширше: від автоматів 3 продажу медикаментів, зоотоварів до промо-автоматів 3 продажу автомобілів. Такі автомати можуть бути оснащені тими самим обладнанням, що і продовольчі, ожнак вимоги до їхнього санітарного стану значно менші, а терміни придатності непродовольчої продукції значно більші, тож і інтервал обслуговування таких автоматів більший. Так само, як і з продовольчими автоматами, узагальнимо структуру класифікації непродовольчих торгових автоматів:

- За консистенцією продовольчого товару: рідкі (автомобільні рідини на розлив, автоматизовані бензоколонки) і паковані (штучні); 
- За принципом видачі продукції: барабанні, ліфтові, спіральні. Рідко зустрічається скриньковий вид видачі продукції.

Слід також зазначити, що вендингові системи торгового напрямку мають, як правило, виконання внутрішнє, тобто їх розміщують в середині приміщення: але і в даному правилі існують виключення. Нерідко зустрічаються кавові автомати і автоматичні диспенсери питної води, які розміщують біля торгових точок на вулиці, або поодаль від людних місць.

Перейдемо до огляду другого сімейства: торгові автомати для надання послуг.

1. Спеціалізовані автомати, які можна об’єднати у групу лише за одною ознакою: логічність їх місцезнаходження або скупчення у одному місці. До цієї групи, в першу чергу, відносяться, розважальні автомати-атракціони, або, як їх ще називають, ігрові автомати.

Досить об'ємний клас вендингових систем, левова частка яких припадає на «дитячий» вендинг.

Це різноманітні вендингові качалки, кран-машини для витягування м'яких іграшок і т.д. Існують і «дорослі» розважальні машини - в таких можна виграти корисний приз або гроші. Досить великий проміжок часу серед ігрових автоматів займали азартні гральні машини («однорукі бандити»), i, треба сказати, що такі машини - це представники найпершого у світі вендингу.

2. Неспеціалізовані вендингові системи для надання послуг - найбільший i найпопулярнішй клас вендингових систем, здатний вирішувати все більше питань людського побуту.

Ця категорія автоматів довгий час була представлена виключно банкоматами і платіжними терміналами, але останнім часом набирають популярності і інші сервіси - автоматичні кіоски копіювання («ксерокси»), вендингові масажні крісла, автомати для зарядки мобільних пристроїв, фотоавтомати для друку фотографій з соцмереж, інформаційні кіоски. 3 екзотичних - манікюрні автомати.

В межах активної роботи з дослідження і розробки вендингових систем, автором і співавторами вказується акцент саме на вендингові системи надання послуг, де різноманіття напрямків розвитку значно перевищує торгові вендингові системи, передумовою до чого може служити їх функціональне безмежжя: скільки існує сфер людського побуту, стільки може існувати різновидів вендингових систем і гілок розвитку автоматичних сервісів.

Аналіз класифікативних характеристик виявляє, що існують і наступні ознаки, притаманні всім вищезазначеним типам і класам вендингових систем:

- За місцем установки вендінгового автомата: вуличні і для установки в приміщеннях;

- За конструкцією: підлогові (більшість існуючих автоматів), настільні і навісні;

- За споживанням електрики: механічні і електричні;

- За розміром торгового автомата: повноростові, напів- та треть- ростові;

- За способом прийому платежу: монетні, готівкові та карткові (банківські термінали);

- За наявістю спеціалізованого обладнання (такого, яке виходить за межі корпусу, наприклад, обладнання автомийок самообслуговування);

- За принципом розміщення: стаціонарні і пересувні;

- За наявністю зворотнього зв'язку: мережеві, комбіновані та відокремлені (самостійні);

- За наявністю функції видачі здачі.

Таким чином, класифікативний аналіз вендингових систем може бути завершено ілюстрацією (рисунок 1).

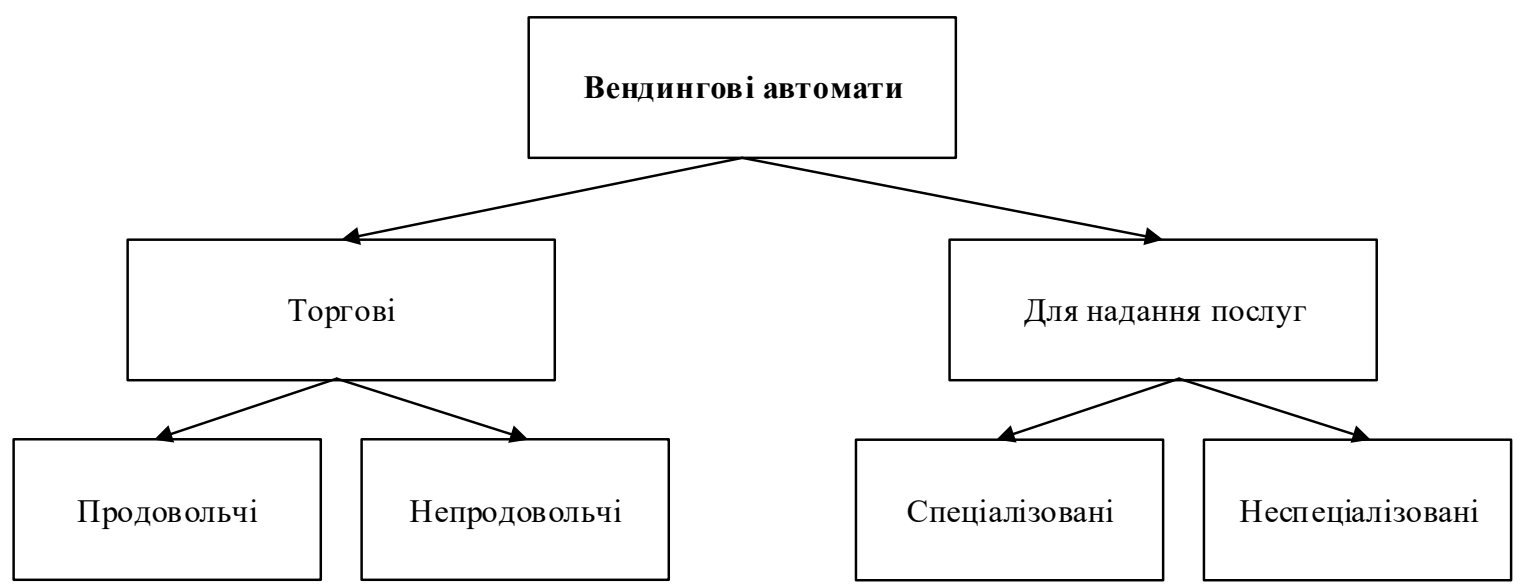

Рисунок 1 - Структурна схема класифікації вендингових систем

() Чернишов К., Майданюк В., Арсенюк I. Малініч I. 
Перейдемо до аналізу історичних передумов існування вендингових систем та аналізу їхньої еволюції.

Аналіз історичних передумов появи різноманіття вендингових систем та їх еволюції. Перш за все слід вдатись до історичного етапу індустріалізації: поява конвеєрного принципу побудови промислового обладнання є відправною точкою в створенні релейних напів-автоматичних систем, які призводять до спрощення і пришидшення ефективності виробництва, не призводячи збільшення робочих місць і використовуючи існуючих працівників з найбільшим коефіцієнтом корисної дії

Саме в цей час активно розвиваються так напрямки розробки, як самостійні електромеханічні комплекси, задача яких ефективно розподілити певні механічні рухи. Це і ліфти, і різноманітні промислові підйомники, і спеціалізовані верстати, військова техніка.

Не секрет, що більшість сучасних технологій прийшли до побуту, будучи розробленими для військових або космічних потреб: стільниковий та супутниковий зв'язок, автомобільна хімія, піротехніка, окремі види та різновиди мікро- та нано- електроніки.

В якості прикладу буде розглянуто автоматичний диспенсер газованої води зразка 1959 року, розроблений СКТБ Харківского завода «Механоліт». Алгоритм його роботи виглядає так:

1. Очікування набору ємності рідини для порції, запалювання зовнішньої підсвітки.

2. Очікування монети (1/3 копійки, звичайна газована вода чи вода з сиропом).

3. Очікування натискання кнопки.

4. Диспенсеризація.

5. Перехід до початку алгоритму.

Як бачимо, алгоритм роботи вендингового автомата досить простий і на кожному кроці пов'язаний з людською взаємодією. По суті, всього два пункти не потребують людського втручання: набір ємності для порції та лиспенсеризація. Таким чином, для реалізації даного алгоритму, вистачить декількох напів-автоматичних пристроїв тригерного типу, взаємодія яких цілком описується теорією автоматів, зокрема принципом побудови автомата Мура. Зовнішній вигляд автомату АТ-26 наведено на рисунку 2 (зліва).

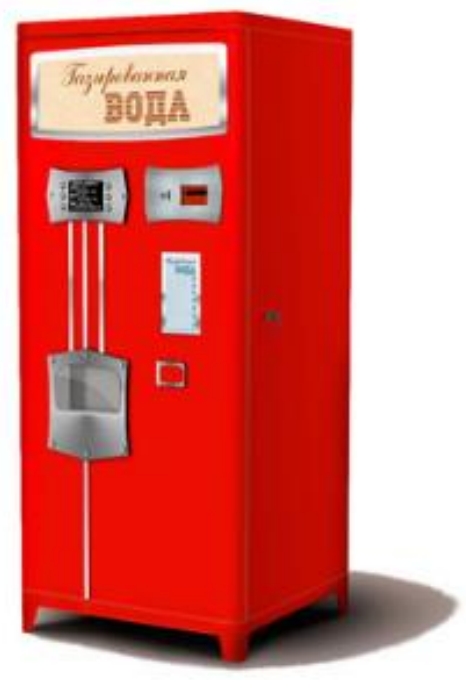

1959

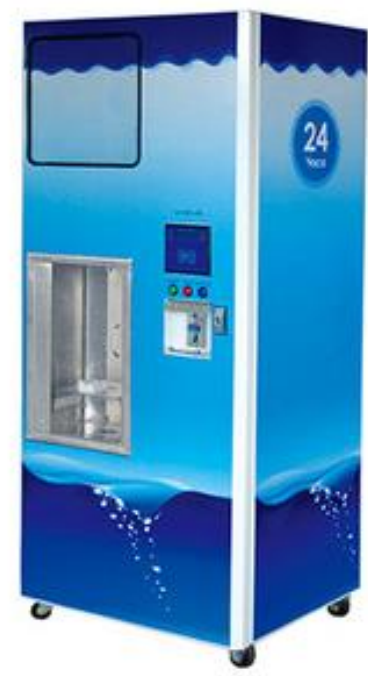

2019

Рисунок 2 - Зовнішній вигляд автоматичних диспенсерів води

Сучасний варіант диспенсера потної води своїм принципом роботи від свого «пращура» відрізняється небагато. Змін зазнали лише спосіб оплати, тепер він передбачає прийом купюр (що стосується значно більш інтелектуального способу аналізу достовірності платіжного засобу), може приймати до оплати картку-абонемент, має графічний інтерфейс відображення кількості та вартості товару в залежності від об’єму, що визначив покупець, має функцію «пауза» (на відміну від 
порційного підходу). I взагалі, система управління сучасним диспенсером базується не на примітивних релейних автоматах, а на мікроконтролері i його управляючому програмному забезпеченні. Алгоритм лишився майже тим самим:

1. Очікування внесення суми коштів.

2. Відображення об’єму води, що відповідає внесеній сумі.

3. Очікування сигналу «Пуск».

4. Диспенсеризація та графічне відображення залишку об’єму.

$5 . \quad$ Очікування натискання кнопки «Пауза».

6. Призупинення або кінець диспенсеризації.

$7 . \quad$ Перехід до початку алгоритму.

Структурна модель сучасного автомату, алгоритм роботи якого розглянуто, буде наведено в наступному розділі.

Аналіз структурних реалізацій сучасних вендингових пристроїв. Оскільки кінцевий продукт знаходиться у надзвичайно динамічному ринку, вибір рішення повинен грунтуватися на вимогах масштабованості та гнучкості застосування без істотної модифікації обраної платформи [4]. Основою будь-якого торгового автомату є плата управління, яку можна будувати, використовуючи такі елементи:

- жорстка логіка;

- універсальні процесори;

- ПЛІС;

- мікроконтролери.

Основним елементом структурної схеми вендінгового автомату (рис. 3) є плата управління, яка координує та контролює роботу усіх вузлів терміналів. За практичної реалізації конкретного виду терміналу конфігурація вузлів у кінцевому виробі може змінюватись залежно від потреб чи побажань замовника.

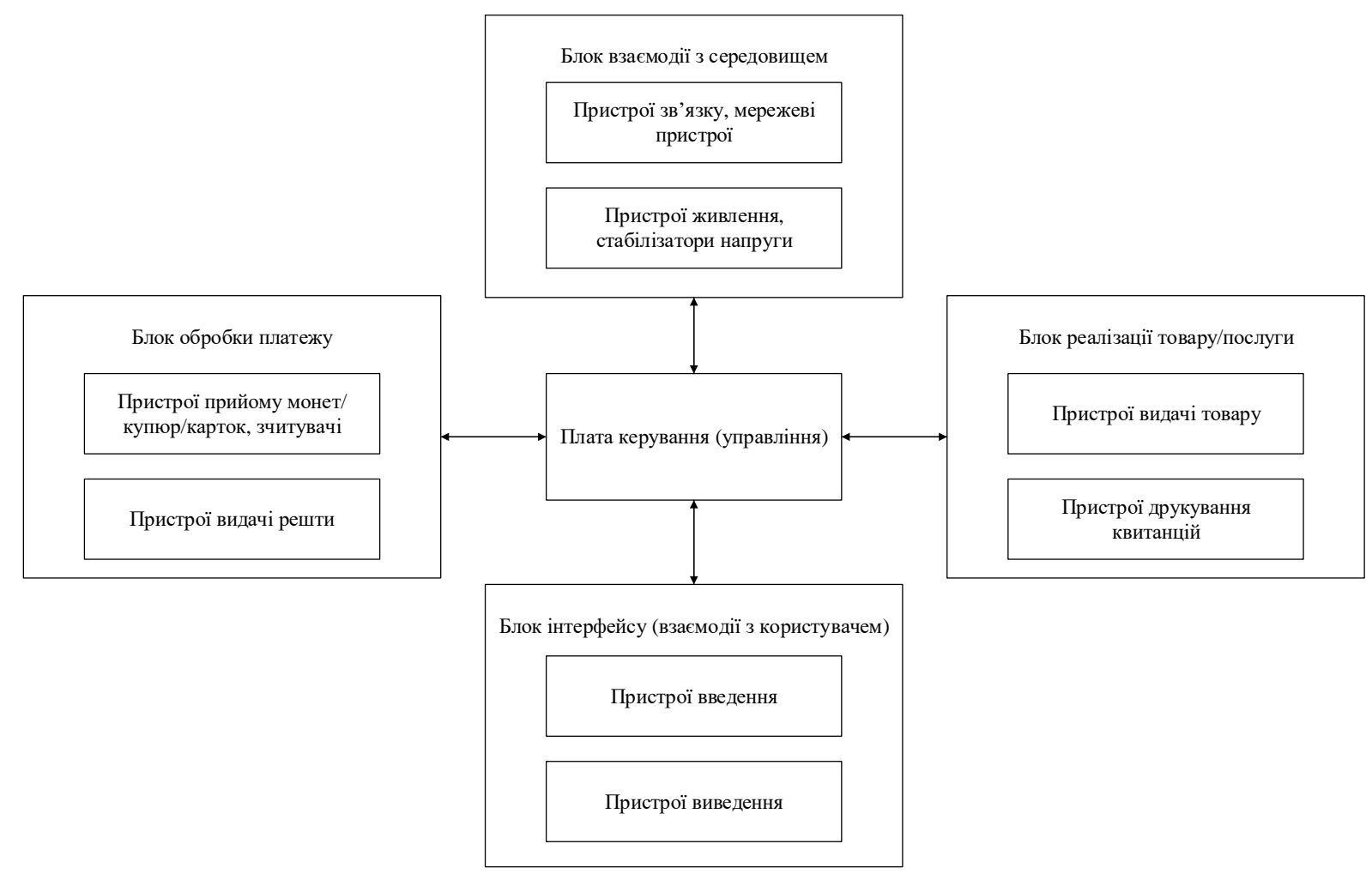

Рис. 3. Структурна схема вендингового автомата

Аналіз типових алгоритмів роботи вендингового автомату. Розглянемо узагальнений алгоритм роботи вендінгового автомату, наведений на рис. 4 . 
Як бачимо з граф-схеми алгоритму, робота автомату починається з первинного налаштування всіх периферійних пристроїв згідно з їх призначенням та особливостями використання у конкретній реалізації автомату.

Далі починається основний цикл алгоритму, а саме: опитування стану периферійних пристроїв, якщо певний 3 пристроїв повідомив про помилку, відбувається спроба перезавантаження та переналаштування цього пристрою, якщо всі пристрої в нормі, аналізують відповіді купюро- та монетоприймачів: чи вніс користувач кошти в автомат чи ні.

Після внесення коштів виділяються серед асортименту ті товари/послуги, які користувач може придбати/отримати за прейскурантом та внесеною сумою. На наступному кроці аналізується відповідь від пристрою введення (клавіатури) - чи було обрано товар/послугу чи ні.

Якщо користувач ще не вибрав жодного товару/послуги, цикл повторюється спочатку. Після вибору товару/послуги, якщо внесена сума є достатньою для купівлі, виконавчому пристрою передається команда видати товар, і цикл повторюється спочатку.

Якщо сума внесених коштів недостатня для придбання обраного товару, користувачеві виводиться відповідне повідомлення, і цикл повторюється спочатку.

Ще одним елементом вендінгового автомату, не внесеним у наведений алгоритм роботи, є система моніторингу за станом автомату [5]. До алгоритма роботи іiі не введено тому, що на кожному кроці алгоритму відбувається подія, яка підлягає протоколюванню з боку системи моніторингу. Система моніторингу є важливим елементом автомату, оскільки дає змогу оперативно фіксувати стан та реагувати на апаратні проблеми. 


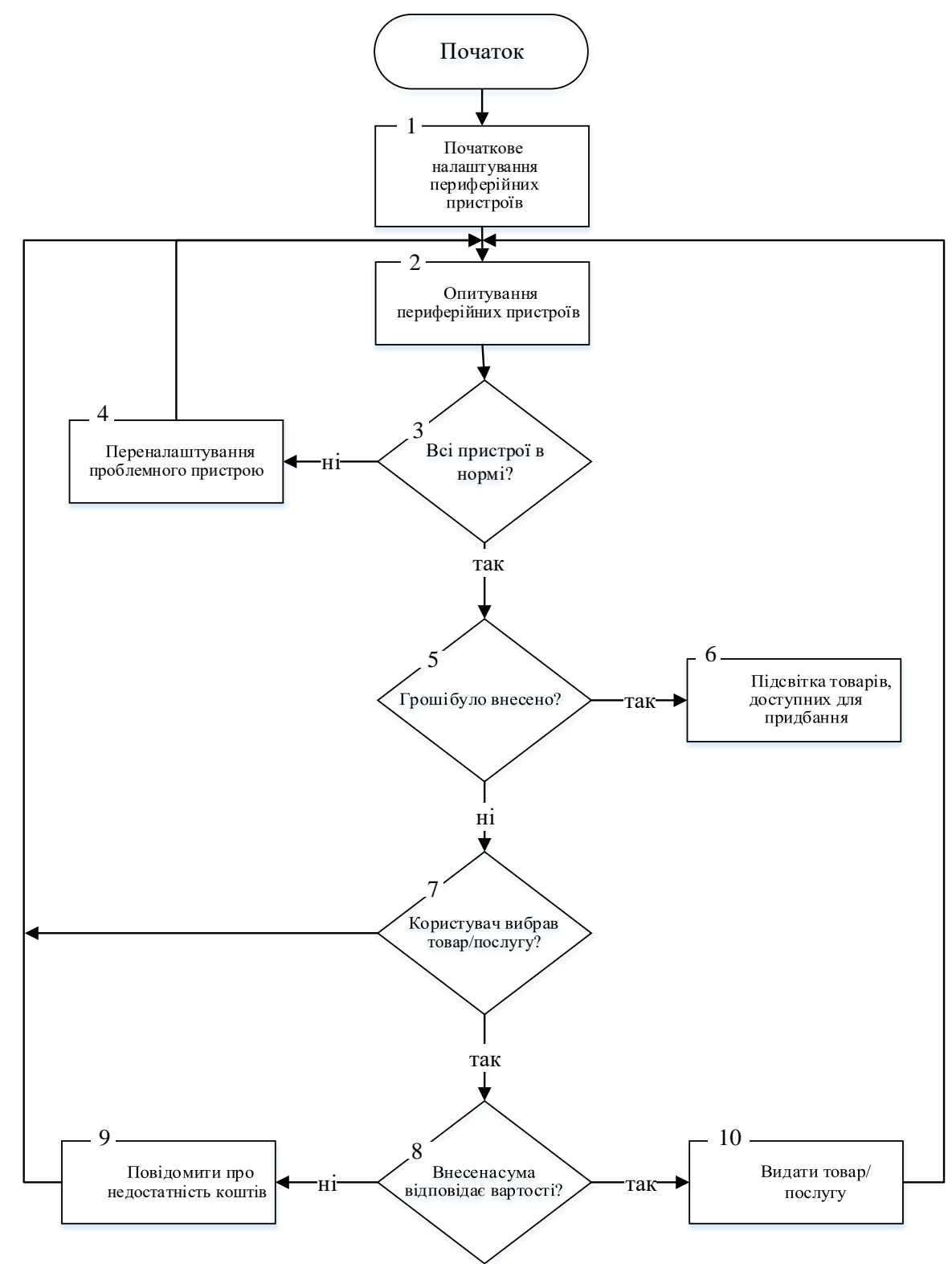

Рис. 4. Типовий алгоритм роботи вендингового автомата

\section{Визначення напрямків розвитку досліджень та розробки вендингових пристроїв}

Найважливішим вектором розвитку безпосередньо вендингових пристроїв та систем в епоху бездротових технологій та безготівкових розрахунків логічніше за все вважати розвиток мережевих зв'язків як всередині вендингових систем, так і між вендинговим пристроєм і клієнтом; пошук та адаптацію новітніх методів оплати послуг автоматів самообслуговування [6].

Авторами запропоновано безготівковий смосіб оплати, алгоритм якого досить просто інтегрується в уже готові вендингові системи, а при створенні нових - легко включається до складу останніх. Запропонований алгоритм безується на клієнт-серверній взаємодії і повинен реалізуватись програмно на окремому керуючому мікроконтролері. В окремих випадках така система оплати послуг або товарів торгового автомату може замінити і навіть виключити зі складу торгового автомату громіздкі, низьконадійні та енергоємні пристрої прийому монет і готівки, видачі решти. Діаграму взаємодії UML алгоритму приведено на рисунку 5. 


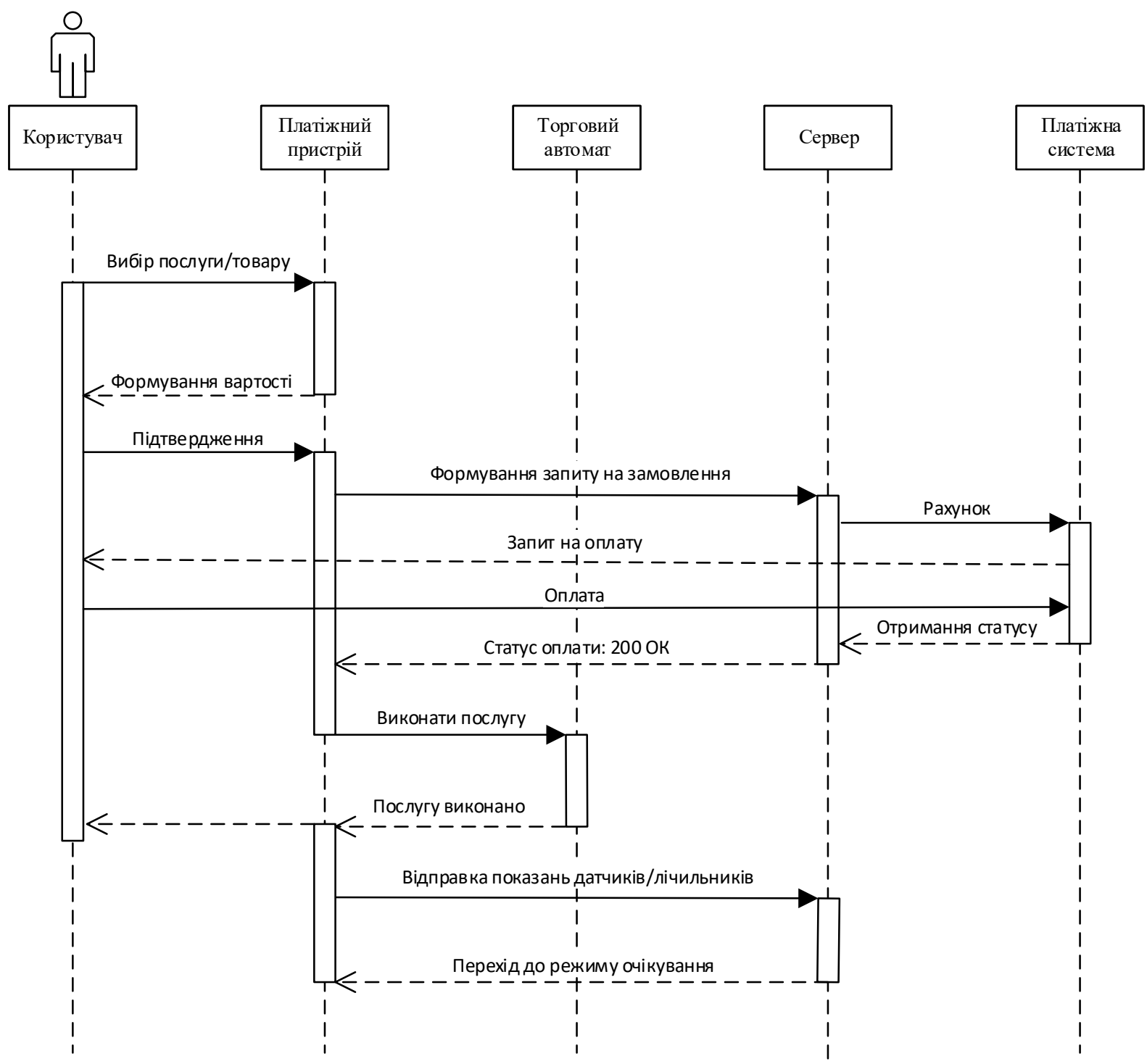

Рис. 5. Алгоритм безготівкової безконтактної оплати послуг вендингової системи

Розглянемо наведений алгоритм детальніше:

1. Користувач вибирає товар, натискає кнопку видачі.

2. Платіжний пристрій надсилає запит серверу з кодом товару.

3. Сервер посилає до АРІ платіжної системи токен на очікування оплати.

4. Платіжна система очікує надходження оплати від користувача

5. Користувач здійснює оплату.

6.. Платіжна система посилає серверу токен з підтвердженням оплати.

7. Сервер відправляє платіжному пристрою підтвердження платежу.

8. Платіжний пристрій перевіряє наявність можливості виконати послугу (додатковий датчик).

9. Платіжний пристрій надсилає сигнал торговому автомату на здійснення операції.

10. Автомат виконує замовлення.

11. Платіжний пристрій отримує від автомата сигнал про виконання замовлення.

12. Платіжний пристрій посилає серверу звіт про виконання замовлення.

13. Сервер відповідає платіжному пристрою завдання перейти в режим очікування.

Наведений алгоритм повністю реалізує безготівкову і безконтактну систему оплати, яка може як доповнити, так і замінити вже існуючу в торговому автоматі систему готівкового розрахунку. Алгоритм 
$€$ універсальним і застосовним в будь-якій як новій, так і існуючій вендинговій системі, реалізацію алгоритму буде продемонстровано в наступній статті, в ході досліджень і розробки предметної галузі.

Що ж стосується напрямків розробки і досліджень нових видів автоматів для впровадження таких у побут людей, то тут думки авторів розходяться, але так чи інакше призводять до спільного висновку: вендингові системи чекає вибух нових розгалужень застосування і різновидів сфер, в які вони можуть втрутитися завдяки дослідженням можливостей технологій останніх поколінь.

Для доведення істинності вищеописаних положень, проведемо аналіз та перелічимо відомі варіації впроваджень автоматичних систем самообслуговування:

- Метрополітен і громадський транспорт (турнікети).

- Класичні роздрібні послуги (громадський телефон і диспенсери питної води, паркомати).

- Харчові торгові автомати (кавові автомати, торгівля снеками.)

- Нехарчові торгові автомати (автомати з продажу бахіл, кондомів).

- Автомати для надання послуг (поповнення рахунку, банківські термінали).

- Вендингові рішення побуту (пральні самообслуговування, автоматичні камери схову).

Формалізуємо деякі $з$ напрямків, в яких необхідно здійснити інваріантний аналіз пошуку технічних рішень:

- СКУД самообслуговування (Автоматичні пропускні пункти до вбиралень).

- Конвеєрно-індустріальні адаптації (системи безперервного циркулювання страв у закладах громадського харчування з системами високої пропускної здатності).

- Миттєве пакування різних груп товарів (гастрономи самообслуговування).

- Багатофункціональні гастрономічні торгові автомати (автомат-кухар).

Висновки. В даній статті авторами порушено низьку питань: роль автоматизації як в науці так і в людському побуті; галузі розробки нових і застосування вже існуючих рішень; доцільність розробки власних способів і методів розрахунку в сучасних вендингових системах; напрямки розвитку існуючих систем самообслуговування.

Список бібліографічних посилань.

1. Чигарин Т.Г. Энциклопедия вендинг-бизнеса. е-Журнал о вендинг-бизнесе. 2011. URL: http://www. e-vending.ru (дата обращения: 01.02.2021).

2. Полушина Е. Как ускорить прибыльность автоматов. «Vendingbusiness». 2008. No.4.: URL: http://www.vendingbusiness.ru/ (дата обращения: 01.02.2021).

3. Золотницький А.P. Теория и практика вендинга. ЭКО, 2004. №7. URL:

http://dspace.nbuv.gov.ua/bitstream/handle/123456789/87023/08-Bobkov.pdf?sequence=1(дата обращения: 01.02.2021).

4. Claude E. Shannon. The Mathematical Theory of Communication. University of Illinois Press, Urbana. 1963. 63 p.

5. Стрелец И.А. Новая экономика и информационные технологии. Москва: Эксмо, 2003. 256 с.

6. Иванова М.А. Торговля через автоматы: мифы и реальность. ЭКО. 2006. № 2. URL:

http://dspace.nbuv.gov.ua/bitstream/handle/123456789/87023/08-Bobkov.pdf?sequence=1(дата обращения: 01.02.2021).

\section{References}

1. Chigarin, T.G. (2011). Encyclopedia of Vending Business. e-Magazine about vending business. URL: http: // www. e-vending.ru (date of access: 01.02.2021).

2. Polushina, E. (2008). How to speed up the profitability of machines. "Vendingbusiness", 4.: URL: http://www.vendingbusiness.ru/ (date of access: 01.02.2021).

3. Zolotnitsky, A.R. (2004).Vending theory and practice. ECO, 7. URL:

http://dspace.nbuv.gov.ua/bitstream/handle/123456789/87023/08-Bobkov.pdf?sequence=1 (date of access: 02/01/2021).

4. Claude, E. Shannon. (1963). The Mathematical Theory of Communication. University of Illinois Press, Urbana. 63 p.

5. Strelets, I.A. (2003). New economy and information technologies. Moscow: Eksmo, 256 p.

6. Ivanova, M.A. (2006). Trading with vending machines: myths and reality. ECO, 2. URL:

http://dspace.nbuv.gov.ua/bitstream/handle/123456789/87023/08-Bobkov.pdf?sequence=1 (date of access: 02/01/2021). 